\title{
Prevalence and Predictors of Dermatophyte Infections Among Primary School Children in Ilemela, Mwanza, Tanzania
}

\author{
Martha F Mushi, ${ }^{a}$ Editha Jonathan, ${ }^{b}$ Mariam M Mirambo, a Stephen E Mshana ${ }^{a}$ \\ aicrobiology and Immunology Department, Catholic University of Health and Allied Science, Weill Bugando School of Medicine, Mwanza, Tanzania; bSchool of \\ Public Health, Catholic University of Health and Allied Science, Mwanza, Tanzania \\ Correspondence to Martha F Mushi (mushimartha@gmail.com)
}

\begin{abstract}
Background: Dermatophytes are highly contagious organisms of public health importance, particularly among primary school children in the resource-limited settings with a prevalence of $10 \%$ to $20 \%$ in East Africa. Here, we report the prevalence and associated factors of dermatophyte infections among primary school children in llemela, Mwanza - Tanzania.

Methods: A cross-sectional study was conducted involving 323 children aged between 4 and 10 years from 10 randomly selected primary schools. The study was conducted between July 2017 and September 2017. Pretested interviewer-administered semi-structured questionnaire was used to collect relevant social-demographic information followed by clinical examination to establish the diagnosis of dermatophyte infections. Data were analysed using Stata version 13.

Results: The mean age of the study participants was $7.63 \pm 1.27$ years, with the slightl majority $(n=183,56.7 \%$ ) of participants being girls. The majority ( $n=277,70.3 \%$ ) of the study participants were from public schools. A total of $299(92.6 \%)$ children reported using tap water at home. Using clinical diagnosis, 94 (29.1\%) children had dermatophyte infections with 92 (97.9\%) of them having tinea capitis. By multivariate logistic regression analysis: being a boy lodds ratio [OR] 1.98; $95 \%$ confidence interval $[\mathrm{Cl}], 1.22$ to $3.22 ; P=.01)$; using lake, river, or well water $(\mathrm{OR} 3.18 ; 95 \% \mathrm{Cl}, 1.36$ to $7.38 ; P<.01)$; playing in a dusty environment (OR 2.65; $95 \% \mathrm{Cl}, 1.28$ to $5.47 ; P<.01)$; playing with animals (OR 2.13; $95 \% \mathrm{Cl}, 1.28$ to 3.56 ; $P<.003)$; and having family members with dermatophyte infections (OR 10.56; $95 \% \mathrm{Cl}, 4.57$ to $24.41 ; P<.001$ ) predicted dermatophyte infections.

Conclusion: The prevalence of dermatophyte infection is high in the study population and is associated with poor hygiene. Improved hygiene will reduce the prevalence of dermatophyte infections among primary school children in low-income countries. Further studies to identify the species and susceptibility patterns of these dermatophytes are recommended to establish empirical treatment guidelines.
\end{abstract}

\section{INTRODUCTION}

$\mathrm{D}$ ermatophyte infections are common superficial fungal infections of public health importance in areas with poor personal and domestic hygiene. ${ }^{1}$ Due to the presence of a low amount of inhibitory fatty acids in the skin of prepubertal children, dermatophyte infections tend to occur more in this age group and mainly affects scalp and skin. ${ }^{2,3}$ In East Africa, the prevalence of dermatophyte infections has been reported to range from $10 \%$ to $20 \%$ among primary school-aged children ${ }^{4-6}$ with limited information from rural areas. Tinea capitis was reported to be endemic in Africa with more than 20 million people affected in the past 4 decades. ${ }^{7}$

Dermatophyte infection is of public health concern due to its contagious nature, as it has been found to be easily transmitted through close skin-to-skin contact with an infected person, sharing of combs and clothes, and playing with domestic animals. ${ }^{4}$ Asymptomatic carriers and the seasonal nature of the disease significantly contribute to dermatophyte transmission between close contacts. ${ }^{8,9}$ The epidemiological distributions of dermatophyte infections have geographical and seasonal variations, depending on the migration of people and climatic conditions. Poor living conditions (overcrowding, poor sanitation, low water supplyn and low socioeconomic status), close contact with infected children, and playing with domestic animals have been found to predispose prepubertal children to dermatophyte infections. ${ }^{4,9}$

Dermatophyte infections can lead to social stigma, resulting in psychosocial trauma to the affected children. The irritation of the affected area due to inflammatory reactions affect children's concentration in class, potentially leading to poor performance and school dropout. ${ }^{4}$ 
TABLE 1. Sociodemographic Characteristics $(\mathrm{N}=323)$

\begin{tabular}{|c|c|}
\hline Variable & n (\%) \\
\hline \multicolumn{2}{|l|}{ Sex } \\
\hline Girls & $183(56.7)$ \\
\hline Boys & $140(43.3)$ \\
\hline Age, years \pm standard deviation & $7.63 \pm 1.27$ \\
\hline \multicolumn{2}{|l|}{ School ownership } \\
\hline Private & $98(30.3)$ \\
\hline Government & $225(69.7)$ \\
\hline \multicolumn{2}{|l|}{ Playground surface } \\
\hline Dust & $258(79.9)$ \\
\hline Cement/grass & $65(20.1)$ \\
\hline \multicolumn{2}{|l|}{ Plays with domestic animals } \\
\hline Yes & $96(29.7)$ \\
\hline No & $227(70.3)$ \\
\hline $\begin{array}{l}\text { Family size, } \\
\text { mean } \pm \text { standard deviation }\end{array}$ & $5.532 \pm 1.967$ \\
\hline \multicolumn{2}{|l|}{ Mode of family } \\
\hline Both parents & $268(83)$ \\
\hline Single parent & $55(17)$ \\
\hline \multicolumn{2}{|l|}{ Source of water } \\
\hline Clean tap water & $299(92.6)$ \\
\hline Lake/well/river & $24(7.4)$ \\
\hline \multicolumn{2}{|l|}{ Towel sharing ${ }^{a}$} \\
\hline Yes & $59(22.3)$ \\
\hline No & $205(77.6)$ \\
\hline \multicolumn{2}{|l|}{ Comb sharing } \\
\hline Yes & $169(52.3)$ \\
\hline No & $154(47.7)$ \\
\hline \multicolumn{2}{|l|}{ Friends with dermatophytosis } \\
\hline Yes & $48(14.9)$ \\
\hline No & $275(85.1)$ \\
\hline \multicolumn{2}{|c|}{ Family member with dermatophytosis } \\
\hline Yes & $289(89.5)$ \\
\hline No & $34(10.5)$ \\
\hline
\end{tabular}

a59 students did not use towels
Additionally, ulceration of the affected area increases susceptibility to secondary bacterial infections.

Despite the physical and psychosocial sequelae that can be brought about by dermatophyte infections, this group of diseases remains neglected in low-income countries. This is partially because most of these fungal infections are benign ${ }^{10}$; as a result, robust epidemiological data are scarce. The present study provides data on the prevalence and factors associated with dermatophyte infections among primary school children in Ilemela, Mwanza, Tanzania. These data are important for identifying the high-risk groups among these children and will inform appropriate preventive strategies.

\section{METHODS}

\section{Study Design and Study Area}

This was a cross-sectional study conducted from July 2017 to September 2017 in primary schools in Ilemela District, Mwanza, Tanzania. According to the national bureau of statistics of Tanzania, Mwanza is the second most densely populated region after Dar es Salaam, with approximately 1,294,761 children aged 0 to 14 years. ${ }^{11}$ Mwanza city has two administrative districts, namely Nyamagana and Ilemela. We chose Ilemela District out of convenience. The district has 74 primary schools and 46 health centres ( 17 public and 29 private). Participating schools were selected at random.

\section{Sample Size, Sampling, and Inclusion Criteria}

The representative target population (323 primary school children) was estimated using Cochran's equation, ${ }^{12}$ assuming a prevalence of $30.4 \%$ based on previous study findings from Dar es salaam, Tanzania. ${ }^{6}$ Ten schools were randomly selected. Pupils were randomly chosen until the desired sample size and distribution across schools was reached.

\section{Data Collection}

A trained nurse used a semistructured, pretested, interviewer-administered questionnaire to collect sociodemographic and clinical data. If a child failed to provide the required information, a checklist was provided to the child's parents to fill. Physical assessment to detect skin lesions suggestive of dermatophyte infection was done. Tinea capitis was defined by the presence of dull, grey, circular patches of alopecia, which is scaling and itching, while tinea corporis was defined by the presence of annular lesions with a clearing, scaly centre surrounded by a red, advancing border that was either dry or vesicular. ${ }^{13}$ Physical assessment and questionnaire administration took about 30 minutes.

\section{Data Management}

The data were entered and cleaned using Microsoft Excel (Microsoft Corp., Redmond, WA, USA) and analysed using Stata version 13 (StataCorp, College Station, TX, USA). Continuous variables, such as age and family size, were summarised using 
TABLE 2. Factors Associated With Dermatophyte Infections Among Primary School Children ( $N=323)$

\begin{tabular}{|c|c|c|c|c|c|}
\hline \multirow{2}{*}{\multicolumn{2}{|c|}{ Variable }} & \multicolumn{2}{|c|}{ Dermatophytes } & \multirow{2}{*}{$\mathrm{X}^{2}$} & \multirow{2}{*}{$P$ Value } \\
\hline & & Yes & No & & \\
\hline Sex & $\begin{array}{l}\text { Girls } \\
\text { Boys }\end{array}$ & $\begin{array}{l}42(22.2 \%) \\
52(37.1 \%)\end{array}$ & $\begin{array}{l}141(77.1 \%) \\
88(62.9 \%)\end{array}$ & 7.7430 & .005 \\
\hline School ownership & $\begin{array}{l}\text { Private } \\
\text { Government }\end{array}$ & $\begin{array}{l}14(14.3 \%) \\
69(35.8 \%)\end{array}$ & $\begin{array}{l}84(85.7 \%) \\
12464.3 \%)\end{array}$ & 14.6899 & .001 \\
\hline Family type & $\begin{array}{l}\text { Single parents } \\
\text { Both Parents }\end{array}$ & $\begin{array}{l}13(36.1 \%) \\
72(26.9 \%)\end{array}$ & $\begin{array}{l}23(63.9 \%) \\
196(73.1 \%)\end{array}$ & 1.3468 & .25 \\
\hline Source of water & $\begin{array}{l}\text { Tape } \\
\text { Lake/well/river }\end{array}$ & $\begin{array}{l}81(27.1 \%) \\
13(54.2 \%)\end{array}$ & $\begin{array}{l}218(72.1 \%) \\
11(45.8 \%)\end{array}$ & 7.8941 & .005 \\
\hline $\begin{array}{l}\text { Playground surface at } \\
\text { school }\end{array}$ & $\begin{array}{l}\text { Not dusty } \\
\text { Dusty }\end{array}$ & $\begin{array}{l}10(15.4 \%) \\
84(32.6 \%)\end{array}$ & $\begin{array}{l}55(84.6 \%) \\
174(67.4 \%)\end{array}$ & 7.4215 & .01 \\
\hline Plays with pets & $\begin{array}{l}\text { No } \\
\text { Yes }\end{array}$ & $\begin{array}{l}55(24.2 \%) \\
39(40.6 \%)\end{array}$ & $\begin{array}{l}172(75.8 \%) \\
57(59.4 \%)\end{array}$ & 8.7904 & .003 \\
\hline $\begin{array}{l}\text { Friend with } \\
\text { dermatophytosis }\end{array}$ & $\begin{array}{l}\text { No } \\
\text { Yes }\end{array}$ & $\begin{array}{l}67(24.4 \%) \\
27(56.3 \%)\end{array}$ & $\begin{array}{l}208(75.6 \%) \\
21(43.8 \%)\end{array}$ & 20.1383 & .001 \\
\hline $\begin{array}{l}\text { Family member with } \\
\text { dermatophytosis }\end{array}$ & $\begin{array}{l}\text { No } \\
\text { Yes }\end{array}$ & $\begin{array}{l}68(23.5 \%) \\
26(76.5 \%)\end{array}$ & $\begin{array}{c}221(76.5 \%) \\
8(23.5 \%)\end{array}$ & 41.3241 & .001 \\
\hline
\end{tabular}

means and standard deviations. Categorical variables were described as proportions and percentages. A stepwise logistic regression analysis was employed to determine factors associated with dermatophyte infection. All factors which were statistically significant on univariate analysis were subjected to multivariate logistic regression analysis. The statistical significance was set at the $95 \%$ confidence level, wherein $P<.05$ was considered statistically significant.

\section{Ethical Considerations}

The study protocol was reviewed and approved by the Joint Catholic University of Health and Allied Sciences/Bugando Medical Centre (CUHAS/BMC) Research Ethics and Eeview Committee (CREC) )certificate no: CREC/274/2017). Students were given information regarding the study and provided with the informed consent form to give to their parents. Children were included if they provided assent and their parents consented.

\section{RESULTS}

\section{Demographic Characteristic of Study Participants}

A total of 323 primary school children were involved in the study, including $183(56.7 \%)$ girls. The mean age of the study participants was $7.6 \pm 1.2$ years, and the mean family size was $5.5 \pm 2$ people. The majority of the children were from public schools $(n=225,69.7 \%)$, and $299(92.6 \%)$ children reported using clean tap water at home (Table 1).

\section{Dermatophyte Infections}

A total of $94(29.1 \%)$ children were clinically diagnosed with dermatophyte infections. The majority $(\mathrm{n}=92,97.9 \%)$ had tinea capitis, with only $2(2.1 \%)$ children diagnosed with tinea corporis. Of 140 boys, $52(37.1 \%)$ had dermatophyte infection compared with $42(22.2 \%)$ of 183 girls children $\left(X^{2}=7.7\right.$; $P<.01)$. There was a significantly higher prevalence of dermatophyte infection among children attending public schools compared with private schools ( $\mathrm{n}=69,35.8 \%$ vs $\mathrm{n}=14,14.3 \%$, respectively; $P<.001$ ) (Table 2 ).

\section{Predictors of Dermatophyte Infections}

Multivariable logistic regression analysis revealed that male gender (adjusted odds ratio [AOR] 2.04; 95\% confidence interval [CI], 1.07 to $3.90 ; P<.029$ ), attending public school (AOR $2.27 ; 95 \% \mathrm{CI}, 1.04$ to $4.98 ; P<.039)$, not changing uniform at least weekly (AOR 4.56; 95\% CI, 1.11 to $18.71, P<.035$ ), playing with domestic animals (AOR 2.04; $95 \%$ CI, 1.3 to 4.02; $P<.030$ ), and sharing of bed sheets (AOR 6.35; $95 \%$ CI, 3.32 to $12.15 ; P<.001$ ) were significant predictors of dermatophyte infections among the participating primary school children (Table 3).

\section{DISCUSSION}

Dermatophyte infections are common and remain an important public health problem among primary school children in resource-limited settings, including Tanzania. This 
TABLE 3. Multivariate Logistic Regression Analysis of Predictors of Dermatophytes

\begin{tabular}{|c|c|c|c|c|c|c|}
\hline Variable & OR & $95 \% \mathrm{Cl}$ & $P$ Value & AOR & $95 \% \mathrm{Cl}$ & $P$ Value \\
\hline \multicolumn{7}{|l|}{ Sex } \\
\hline Female & 1 & & & 1 & & \\
\hline Male & 1.98 & $1.22-3.22$ & .01 & 2.04 & $1.07-3.90$ & .029 \\
\hline \multicolumn{7}{|l|}{ Type of school } \\
\hline Private & 1 & & & & & \\
\hline Government & 3.34 & $1.76-6.32$ & .001 & 2.27 & $1.04-4.98$ & .08 \\
\hline \multicolumn{7}{|l|}{ Type of family } \\
\hline Single mother/guardian & 1 & & & & & \\
\hline Both parents & 0.64 & $0.31-1.35$ & .25 & ----- & ----- & -------- \\
\hline \multicolumn{7}{|l|}{ Source of water } \\
\hline Tap & 1 & & & & & \\
\hline Lake/river/well & 3.18 & $1.36-7.38$ & .01 & 2.49 & $0.87-7.10$ & .08 \\
\hline \multicolumn{7}{|l|}{ Reported towel sharing } \\
\hline No & 1 & & & & & \\
\hline Yes & 1.25 & $0.65-2.39$ & .49 & ---- & $-\cdots--$ & ----- \\
\hline \multicolumn{7}{|c|}{ Frequency of changing school uniform within a week } \\
\hline Twice & 1 & & & & & \\
\hline Once & 1.33 & $0.81-2.20$ & .25 & 1.22 & $0.62-2.39$ & .55 \\
\hline None & 2.97 & $0.97-9.02$ & .05 & 4.56 & $1.11-18.71$ & .035 \\
\hline \multicolumn{7}{|l|}{ Playground surface } \\
\hline Not dusty & 1 & & & & & \\
\hline Dusty & 2.65 & $1.28-5.47$ & .01 & 1.71 & $0.71-4.13$ & .23 \\
\hline \multicolumn{7}{|l|}{ Reported playing with animals } \\
\hline No & 1 & & & & & \\
\hline Yes & 2.13 & $1.28-3.56$ & .003 & 2.04 & $1.03-4.02$ & .038 \\
\hline \multicolumn{7}{|c|}{ Reported having family members with dermatophytes } \\
\hline No & 1 & & & & & \\
\hline Yes & 10.56 & $4.57-24.41$ & .001 & 7.66 & $2.75-21.26$ & .0011 \\
\hline \multicolumn{7}{|c|}{ Reported sharing of bed sheets } \\
\hline No & 1 & & & & & \\
\hline Yes & 5.62 & $3.34-9.45$ & .001 & 6.35 & $3.32-12.15$ & .001 \\
\hline
\end{tabular}

was evident in the present study whereby about one-third of children had dermatophyte infections. The observed prevalence was similar to the $30.4 \%$ and $33.3 \%$ reported among primary school children in Dar es Salaam and Kenya, respectively. ${ }^{2,6}$ Nevertheless, the reported prevalence was lower than what was reported in other previous studies conducted in Af- rica - 59\% in Ethiopia ${ }^{14}$ and $81.2 \%$ in Kenya, for example ${ }^{15}$. The observed differences could be explained by the differences in the study populations; in the previous studies, the majority of children were from slums and public schools, while the present study involved both public and private schools. 
As has been previously observed elsewhere, ${ }^{15-18}$ the prevalence of dermatophyte infections in the present study was significantly higher among boys compared with girls. The higher prevalence among boys has been attributed to several factors, such as poorer personal hygiene, sharing of combs, playing in dust, sharing of towels, and interacting and playing with friends without considering personal hygiene. ${ }^{5-18}$ It should be noted that studies conducted in Nigeria and Egypt reported significantly higher prevalences of dermatophyte infections among girls compared with boys. ${ }^{19,20}$

As observed in previously, ${ }^{9}$ tinea capitis was the predominant dermatophyte infection detected in this study. Male gender, having family member with a dermatophyte infection, not using tap water, and sharing combs significantly predicted tinea capitis. Similar observations have been reported from previous studies ${ }^{9,15,18,21,22}$ investigating primary school children.

This work was limited by a lack of capacity for fungal culture; dermatophyte infection was solely a clinical diagnosis, and this might have inflated the prevalence findings.

\section{CONCLUSION}

A high proportion of children with poor hygiene had tinea capitis. Health education tailored to boys regarding personal hygiene will significantly reduce the burden of dermatophyte infections. Further studies should be conducted to identify the patterns and distributions of the dermatophyte species that cause these common infections in children.

Acknowledgements: Authors would like to acknowledge the support provided by Schools administration during data collection of this study. In addition, we thank all parents/guardians for allowing their children to participate in the study.

\section{REFERENCES}

1. Yu J, Li R, Bulmer G: Current topics of tinea capitis in China. Nihon Ishinkin Gakkai Zasshi. 2005;46(2):61-66. CrossRef. Medline

2. Ayaya SO, Kamar KK, Kakai R. Aetiology of tinea capitis in school children. East Afr Med J. 2001;78(10):531-535. Medline

3. Greenwood D, Slack RCB, Peutherer JF. Medical Microbiology: A Guide to Microbial Infections, Pathogenesis, Immunity, Laboratory Diagnosis, and Control. 16th ed. Edinburgh: Churchill Livingstone; 2002.

4. Chepchirchir A, Bii C, Ndinya-Achola JO. Dermatophyte infections in primary school children in Kibera slums of Nairobi. East Afr Med J. 2009;86(2):59-68. Medline

5. Edhonu-Elyetu F. Communicable ectoparasitic and fungal skin diseases among five to fifteen year old children in Kaloleni Division, Kilifi District, Coast Province, Kenya. MPH Thesis. Nairobi, Kenya: University of Nairobi; 1991.

6. Komba EV, Mgonda YM. The spectrum of dermatological disorders among primary school children in Dar es Salaam. BMC Public Health. 2010;10:765. CrossRef. Medline
7. Verhagen AR. Distribution of dermatophytes causing tinea capitis in Africa. Trop Geogr Med. 1974;26(2):101-120. Medline

8. Ive FA. The carrier stage of tinea capitis in Nigeria. Br J Dermatol. 1966;78(4):219-211. CrossRef. Medline

9. Figueroa JI, Hawranek T, Abraha A, Hay RJ. Tinea capitis in south-western Ethiopia: a study of risk factors for infection and carriage. Int J Dermatol. 1997;36(9):661-666. CrossRef. Medline

10. Shrum JP, Millikan LE, Bataineh $O$. Superficial fungal infections in the tropics. Dermatol Clin. 1994;12(4):687-693. Medline

11. National Bureau of Statistics (NBS) [Tanzania], Office of Chief Government Statistician (OCGS) [Zanzibar]. Population and Housing Census - Population Distribution by Age and Sex. Dar es Saalam, Tanzania: NBS and OCGS; 2013. http://catalog.ihsn.org/index.php/catalog/4618/download/58602. Accessed 6 August 2019.

12. Cochran WG. Sampling Techniques. 2d ed. New York: Wiley; 1963.

13. Sarabi K, Khachemoune A. Tinea capitis: a review. Dermatol Nurs. 2007;19(6):525-529. Medline

14. Woldeamanuel Y, Leekassa R, Chryssanthou E, Menghistu Y, Petrini B. Prevalence of tinea capitis in Ethiopian schoolchildren. Mycoses. 2005;48(2):137141. CrossRef. Medline

15. Moto JN, Maingi JM, Nyamache AK. Prevalence of tinea capitis in school going children from Mathare, informal settlement in Nairobi, Kenya. BMC Res Notes. 2015;8:274. CrossRef. Medline

16. Ménan ElH, Zongo-Bonou $O$, Rouet F, Kiki-Barro PC, Yavo W, Névabi F, Koné $M$. Tinea capitis in schoolchildren from lvory Coast (western Africa). A 1998-1999 cross-sectional study. Int J Dermatol. 2002;41(4):204-207. CrossRef. Medline

17. Ezeronye O. Distribution of dermatomycoses in cross river upstream bank of Eastern Nigeria. In: Medical Mycology: The African Perspectives - Proceedings of an International Conference Held at Hartenbosch, South Africa. 2005.

18. Enendu N, lbe S. Prevalence of tinea capitis among primary school pupils in Uli, Anambra State, Nigeria. Afr J Appl Zool Environ Biol. 2005;7(1):1-4. CrossRef

19. Omar AA. Ringworm of the scalp in primary-school children in Alexandria: infection and carriage. East Mediterr Health J. 2000;6(5-6):961-967. Medline

20. Anosike JC, Keke IR, Uwaezuoke JC, et al. Prevalence and distribution of ringworm infections in Primary school children in parts of Eastern, Nigeria. J Appl Sci Environ Manage. 2005;9(3):21-26. CrossRef

21. Wu YH, Su HY, Hsieh YJ. Survey of infectious skin diseases and skin infestations among primary school students of Taitung County, eastern Taiwan. J Formos Med Assoc. 2000;99(2):128-134. Medline

22. Kundu D, Mandal L, Sen G. Prevalence of Tinea capitis in school going children in Kolkata, West Bengal. J Nat Sci Biol Med. 2012;3(2):152-155. CrossRef. Medline

Peer Reviewed

Competing Interests: None declared.

Received: 24 Aug 2018; Accepted: 25 Jun 2019

Cite this article as: Mushi MF, Jonathan E, Mirambo MM, Mshana SE. Prevalence and Predictors of Dermatophyte Infections Among Primary School Children in Ilemela, Mwanza, Tanzania. E Afr Health Res J. 2019;3(1):\#\#-\#\#. http://doi. org/10.24248/EAHRJ-D-18-00033

(C) Mushi et al. This is an open-access article distributed under the terms of the Cre ative Commons Attribution License, which permits unrestricted use, distribution, and reproduction in any medium, provided the original author and source are properly cited. To view a copy of the license, visit http://creativecommons.org/licenses/ by/4.0/. When linking to this article, please use the following permanent link: http:// doi.org/10.24248/EAHRJ-D-18-00033. 